\title{
Carvedilol alkalmazása a mindennapi kardiológiai és intervenciós kardiológiai gyakorlatban
}

\author{
Kónyi Attila dr. \\ Pécsi Tudományegyetem, Általános Orvostudományi Kar, Klinikai Központ, Szívgyógyászati Klinika, Pécs
}

\begin{abstract}
A súlyos koszorúér-szúküuletek stentimplantációval történő kezelése igen effektív terápia, azonban a háló beültetésével az alapproblémát, az atherosclerosist nem oldjuk meg. Ezért is nagyon lényeges az életmódbeli változtatások mellett a megfelelő gyógyszeres terápia. A béta-blokkolók a katéterezésre tervezetten vagy akutan kerülő betegek esetén igen nagy százalékban a gyógyszeres terápia alapját képezik. A csoport tagjai azonban hatástanilag jelentős eltéréseket mutatnak. A harmadik generációs béta-blokkoló, vasodilatator carvedilol komplex hatású, mind adrenergblokkoló, mind kalciumcsatorna-blokkoló effektussal is rendelkezik. A kedvező tulajdonságok hátterében emellett fontos szerepet játszik szabadgyökcsapda-effektusa, amellyel a béta-blokkolók többsége nem rendelkezik. Emiatt, mint számos nagy tanulmány igazolta, igen előnyös hypertoniában, myocardialis infarctus után, diabetesben és szívelégtelen betegek esetén is. Az intervenciós gyakorlatban kifejezetten érvényre jutnak ezek a pozitív hatások, mivel a szívkatéterezésre kerülő betegek nagy százalékban hypertoniások, diabetesesek vagy hyperlipidaemiások. Kifejezetten előnyös az antioxidáns hatása, valamint simaizomproliferáció-gátló hatása, amely esetlegesen az in-stent restenosis (ISR) kialakulását is kedvezően befolyásolhatja. Összességében vasculoprotectiv hatása miatt ideális választás stentbeültetést követően a mindennapi gyakorlatban.
\end{abstract}

Orv Hetil. 2017; 158(37): 1453-1457.

Kulcsszavak: béta-blokkolók, carvedilol, intervencionális kardiológia, stentimplantáció, hypertonia

\section{Carvedilol in every day cardiology and interventional cardiology practice}

The treatment of severe coronary stenoses with stent implantation is very effective nevertheless, the underlying problem of atherosclerosis remains unsolved with the implantation of a stent. Therefore, besides lifestyle changes, the adequate medication therapy is of pivotal importance. In the majority of patients scheduled for or acutely undergoing catheterisation, beta-blockers form the basis of medication therapy. Members of the group, however, show significant differences in terms of pharmacodynamics. The third-generation beta-blocker and vasodilator carvedilol possesses complex adrenerg-blocking and Ca-channel blocking effects as well. In the background of the favourable effects, a further positive property is its anti-free-radical effect which most beta-blockers do not have. Therefore, as has been proven by several studies, it provides considerable benefits in hypertension, after myocardial infarction, in diabetes and also in the treatment of patients with cardiac failure. These positive effects have been markedly observed in interventional cardiology practice, as the majority of patients undergoing cardiac catheterisation have hypertension, diabetes or hyperlipidaemia. Its anti-free-radical effect is especially beneficial together with its smooth muscle proliferation-inhibitor effect which may favourably affect in-stent restenosis (ISR) as well. To summarise, due to its vasculoprotective effect, carvedilol is an ideal drug of choice following stent implantation in routine everyday practice.

Keywords: beta-blockers, carvedilol, interventional cardiology, stent implantation, hypertonia

Kónyi, A. [Carvedilol in the everyday interventional cardiology practice]. Orv Hetil. 2017; 158(37): 1453-1457.

(Beérkezett: 2017. május 23.; elfogadva: 2017. augusztus 7.) 


\section{Rövidítések}

$\mathrm{ACE}=$ (angiotensin-converting enzyme) angiotenzinkonvertáló enzim; BMS = (bare metal stent) hagyományos fémstent; $\mathrm{CO}=$ cardiac output COMET $=$ Carvedilol or Metoprolol European Trial; $\mathrm{COPD}=($ chronic obstructive pulmonary disease $)$ krónikus obstruktív tüdőbetegség; DES = (drug-eluting stent) gyógyszerkibocsátó stent; IS = (insulin sensitivity) inzulinszenzitivitás; ISA = (intrinsic sympathomimetic activity) intrinszik szimpatomimetikus aktivitás; ISR $=$ in-stent restenosis; $\mathrm{PAD}=$ (peripheral artery disease) perifériás érbetegség; $\mathrm{PCI}=$ (percutaneous coronary intervention) percutan coronariaintervenció

A percutan coronariaintervenciók terén jelentős fejlődést láthattunk az elmúlt két évtizedben. A hagyományos fémstenteket (bare metal stent - BMS), amelyek esetében a restenosisarány egyes esetekben akár a 30-40\%-ot is elérte [1], felváltották a gyógyszerkibocsátó hálók (drug-eluting stent - DES), amelyek esetében a visszaszúkülési arány jelentôs mértékben redukálódott [2]. Az első generációs DES-kek megjelenésével sem állt meg a fejlesztés, második, majd harmadik generációs gyógyszerkibocsátó hálók jelentek meg, új hatóanyagokkal és új polimer koncepcióval. Ezáltal nemcsak a restenosisráta csökkent tovább, hanem az akut stentthrombosis gyakorisága is javult, amely pozitív folyamatot az újonnan kifejlesztett thrombocytaaggregációs gyógyszerek is támogatták (clopidogrel, prasugrel, ticagrelol, cangrelor).

$\mathrm{Az}$ újabb stentek megjelenése ellenére az intervenciós kardiológusok számára a restenosis kérdése továbbra is az egyik legégetőbb kérdéskör. Emiatt is lényeges, hogy a PCI-re kerülő betegek esetén a terápia ne érjen véget a stent behelyezésével, minden farmakológiai lehetôséget be kell a betegek terápiájába építeni, amellyel csökkenthetjük a restenosisarányt, valamint az új (de novo) szúkületek kialakulásának esélyét is redukálhatjuk.

A béta-blokkolók, amelyekról számos tanulmány igazolta az ischaemiás szívbetegség különböző klinikai megjelenési formájában látható mortalitáscsökkentő hatásukat, a katéterezésre tervezetten vagy akutan kerülő betegek esetén is igen nagy százalékban a gyógyszeres terápia alapját képezik. A csoport tagjai azonban hatástanilag jelentős eltéréseket mutatnak. Míg az első generációs béta-blokkoló szerek mind a béta-1- és a béta-2-receptorokat is blokkolják (nem szelektív béta-blokkolók), addig a második generációs szerek elsősorban a szívben és a szervezet egyéb helyein megtalálható béta-1-receptorokra hatnak. A harmadik generációs szerek esetén már nem a béta-1-szelektivitás növelése volt a cél, ezek a szerek a vasodilatatióból adódó pozitív hemodinamikai hatás mellett cardiovascularis protektív hatással is rendelkeznek. E gyógyszercsoport tagja a carvedilol, amely a többi béta-blokkolóhoz képest számos unikális hatással rendelkezik az antiischaemiás hatás mellett, amelyet a szívfrekvencia- és kontraktilitáscsökkentés révén ér el, csökkenti a neutrofil infiltrációt, az apoptózist, a simaizomsejt-migrációt és pozitív hatással van az infarktus utáni remodellingre [3].

\section{A carvedilol hatásmechanizmusa, farmakológiai profilja}

A harmadik generációs béta-blokkoló carvedilol hatása komplex, mind adrenergblokkoló, mind kalciumcsatorna-blokkoló hatással is rendelkezik. Kis koncentrációban is jelentkező kompetitív béta-blokkoló hatása nem szelektív, viszont alfa $_{1}$-receptor-antagonizmusa szelektív, csak igen magas koncentrációban és állati szövetekben hat alfa ${ }_{2}$-receptorokon. Alfa-adrenerg-blokkoló hatása viszont csak körülbelül tizedannyi, mint béta-blokkoló hatása [4].

Kalciumcsatorna-blokkoló effektusa csak nagyobb dózisban jelentkezik ( $>1 \mu \mathrm{M})$, és mai tudásunk szerint ennek nincs szerepe a carvedilol vérnyomáscsökkentő hatásában. Intrinszik szimpatomimetikus aktivitása (ISA) nincs.

Gyorsan felszívódik orális adagolásnál, maximális plazmakoncentrációját egy-két órán belül eléri, felezési ideje 7-10 óra, emiatt naponta kétszer kell adagolni. A plazmában 98\%-ban proteinekhez kötődik, főképp albuminhoz, kizárólag a májban metabolizálódik [5].

Antihipertenzív effektusát a perifériás vascularis rezisztencia csökkentésével éri el, amelyet a béta-adrenerg-blokád egyidejű jelenléte miatt reflextachycardia nem kísér.

Anyagcsere-semlegessége és kifejezett alfa- és béta-receptortól független antioxidáns tulajdonsága révén jelentős vasculoprotectiv effektusú.

Klinikai vizsgálatokban igazolták pozitív hatását cardialis dekompenzáció esetén, hypertoniás betegek célszervvédelmében és az ischaemiás szívbetegségek primer és szekunder prevenciójában. A kedvező hatások hátterében fontos szerepet játszik szabadgyökcsapda-effektusa, amellyel a béta-blokkolók többsége nem rendelkezik. A cardiovascularis betegségek kialakulásában központi szerepet játszanak az inflammatorikus faktorok, a szabad gyökök és a vascularis károsodás prognosztikai markerének tekinthető, következményes akutfázis-fehérjék. Amennyiben a glükóz, a vérzsírok szintje, az intraluminalis nyomás a normális tartománynál magasabb, akkor ez beindítja különböző szabad gyökök fokozott termelését. Ezeket a molekulákat - elsősorban a szuperoxidot termelő enzimek fokozott múködése figyelhető meg a cardiovascularis betegségcsoportokban. A carvedilol antiinflammatorikus hatása alapvetően antioxidáns (scavenger) és szabadgyök-szuppresszív tulajdonságaiból következik. Komplex adrenergblokkoló hatásán túl ez a képessége ad molekuláris magyarázatot kemény végpontú, klinikai vizsgálatok által igazolt hatékonyságára [6].

\section{A carvedilolterápia indikációs területei}

\section{Carvedilol alkalmazása bypertoniában és egyéb cardiovascularis rizikófaktorok esetén}

A carvedilol kedvező hatású hypertoniában, szemben a tradicionális béta-blokkolókkal, antihipertenzív effektusát fóképp a perifériás vascularis rezisztencia csökkenté- 
sével éri el. A nem vasodilatator béta-blokkolók antihipertenzív hatása a csökkent cardiac outputtal (CO) és szimpatikus aktivitással, valamint, egyes feltételezések szerint, a reninkibocsátás csökkenésével magyarázható, míg a vascularis rezisztencia esetükben változatlan vagy akár emelkedett lehet [7].

Ezzel szemben a carvedilol nincs negatív hatással a CO-ra, ezáltal antihipertenzív hatása inkább az ACEgátlókéhoz vagy a kalciumcsatorna-blokkolókéhoz hasonlítható, így vérnyomáscsökkentő hatása jóval kiegyensúlyozottabb, mint a hagyományos béta-blokkolóké [7].

Az elmúlt években megjelent néhány vizsgálat (LIFE, ASCOT), amelyeknek adatai alapján a tradicionális bétablokkolók anyagcserehatása kedvezőtlen lehet az inzulinszenzitivitás (IS), ezáltal a diabetes incidenciája, valamint a lipidparaméterek tekintetében.

Jelentős számú nemzetközi vizsgálat adatai alapján igazolódott, hogy egyes béta-blokkolók, a tiazid típusú diuretikumokhoz hasonlóan, rontják az IS-t, ezáltal növelik a hypertoniás betegcsoportban az új keletú diabetes kialakulásának esélyét, míg az ACE-gátlók, ARB-k, kalciumcsatorna-blokkolók neutrálisak vagy akár pozitív hatással rendelkeznek ebben a tekintetben [8].

Például a COMET (Carvedilol or Metoprolol European Trial) vizsgálatban az új keletú diabetes kialakulása $22 \%$-kal kevesebb volt a carvedilolcsoportban, mint azoknál a betegeknél, akik metoprololt kaptak. Ezek az adatok egyértelmúen támogatják azt az elvet, hogy a hypertoniás populációban azoknál a betegeknél, akiknél metabolikus szindróma, csökkent glükóztolerancia vagy manifeszt diabetes igazolódik, a vasodilatator hatású béta-blokkolókat kell előnyben részesíteni (1.ábra).

Lipidparaméterek tekintetében szintén kedvezőtlen egyes, nem kardioszelektív tradicionális béta-blokkolók anyagcsereprofilja. Ismert, hogy emelik a trigliceridszintet és csökkentik a HDL-szintet [9-11].

A régebbi béta-blokkolókkal szemben a carvedilol neutrális a lipoproteinlipáz-aktivitásra és a triglicerid-, valamint HDL-szintekre [12, 13].

A carvedilol ezen pozitív anyagcsereprofilja további előnyt jelent metabolikus szindrómában is szenvedő hypertoniás betegek esetén.

\section{Carvedilol akut myocardialis infarctust követöen}

Számos nagy nemzetközi, randomizált vizsgálat igazolta a béta-blokkolók kedvező hatását posztinfarktusos betegekben. Pozitív hatásuk kialakításában a szívizom oxigénfogyasztásának, a falfeszülésnek, a szívfrekvenciának, vérnyomásnak a csökkentése áll. Ezen hatások miatt redukálódik az infarktusos terület, a ritmuszavarok, illetve a szívizomruptura veszélye csökken.

A CAPRICORN vizsgálatban csökkent balkamrafunkciójú ( $\mathrm{EF} \leq 40 \%)$ posztinfarktusos betegeket (1958 beteg) randomizáltak az AMI után 21 napon belül [14]. A vizsgálatban az alfa-receptor-blokkoló és antioxidáns

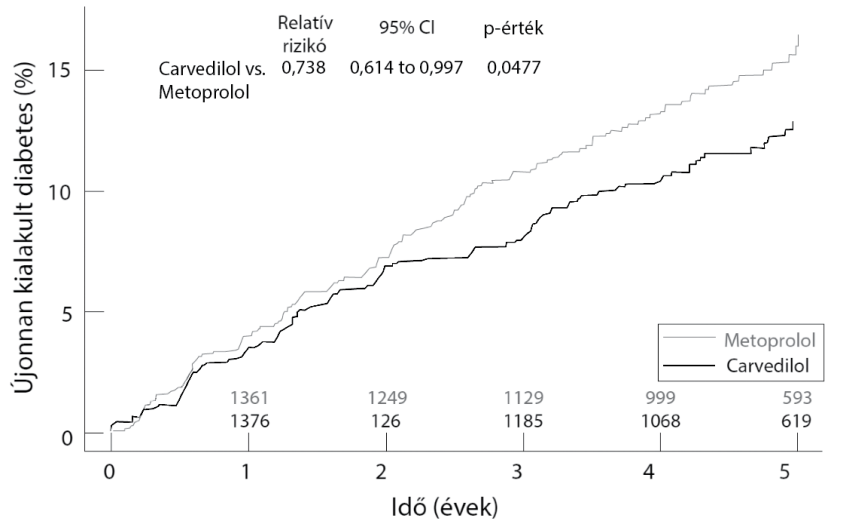

1. ábra

Az újonnan kialakult diabetes százalékos aránya a metoprolol- és carvedilolcsoportban a COMET vizsgálat eredménye alapján (Heart 2007; 93: 968-973)

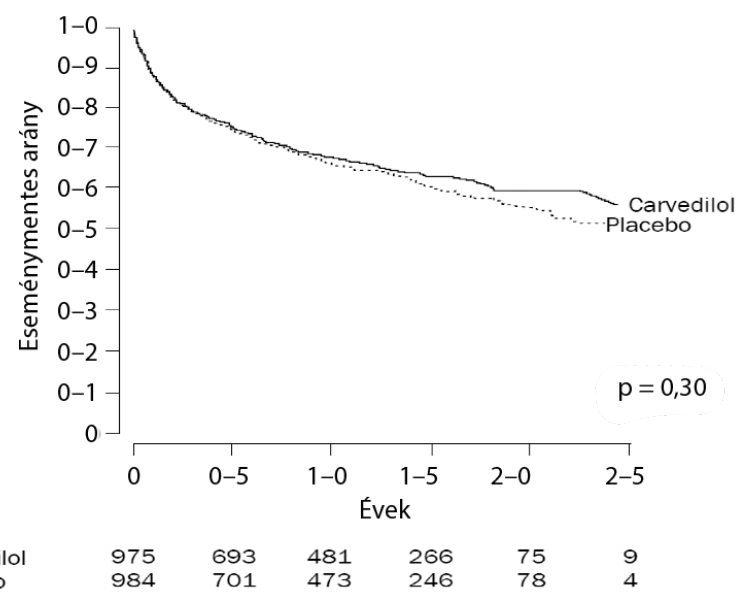

2. ábra $\quad$ Az összmortalitás relatív rizikója a CAPRICORN vizsgálat carvedilol-, valamint placebocsoportjában (Lancet 2001; 357: 1385-1390)

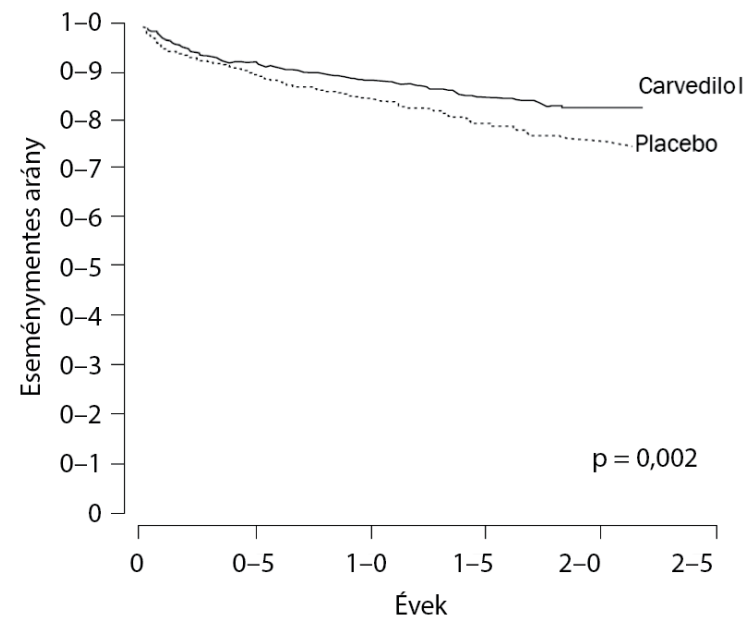

$\begin{array}{lllllll}\text { Carvedilol } & 975 & 842 & 634 & 355 & 108 & 15\end{array}$ $\begin{array}{llllllr}\text { Placebo } & 984 & 834 & 615 & 338 & 112 & 8\end{array}$

3. ábra $\quad$ A nem fatális re-infarktus relatív rizikója a CAPRICORN vizsgálat carvedilol-, valamint placebocsoportjában (Lancet 2001; 357: 1385-1390) 
tulajdonsággal is rendelkező nem szelektív béta-receptor-blokkoló carvedilolt hasonlították össze placebóval. A vizsgálat adatai szerint az átlagosan 1,3 éves utánkövetés során a carvedilol 23\%-kal csökkentette az összmortalitás relatív rizikóját a placebocsoporthoz képest (2. ábra), emellett a rekurrens nem fatális myocardialis infarctusok számát is szignifikánsan csökkentette (3. ábra) [14].

A CAPRICORN vizsgálat echokardiográfiás alvizsgálatában ACE-gátló terápia mellett alkalmazott carvedilol bal kamrai remodellingre kifejtett pozitív hatását elemezték akut myocardialis infarctust követően. Az eredmények alapján a carvedilol szignifikánsan csökkentette a progrediáló remodellinget szívinfarktust követően bal kamrai diszfunkciós betegek esetén [15].

Összefoglalva elmondható, hogy a béta-blokkoló kezelés posztinfarktusos betegcsoportban bázisterápiának számít, és ha nincs kontraindikáció, minden esetben szükséges alkalmazása.

A béta-blokkoló kiválasztásánál a harmadik generációs szerek egyértelműen előnyben részesülhetnek, ha a beteg metabolikus szindrómában, diabetesben vagy perifériás érbetegségben (PAD) szenved, ső́t a COLA vizsgálat adatai alapján még COPD-ben szenvedő betegek is több mint $80 \%$-ban tolerálják a carvedilolt [16].

\section{Carvedilol szivelégtelenségben}

Míg évtizedekkel ezelőtt kontraindikáció volt, a szívelégtelen betegek esetén ma már a megfelelően feltitrált béta-blokkoló adása a standard terápia része. Számos, jelentős betegszámú nemzetközi vizsgálat (például MDC, CIBIS I, CIBIS II, MERIT-HF, ANZ, US Carvedilol Study, BEST, COPERNICUS, CAPRICORN) igazolta, hogy a hosszú távú béta-blokkoló kezelés jelentős mértékben javítja a krónikus szívelégtelen betegek túlélését, életminőségét, a hospitalizációk számát. Sok esetben azonban a mellékhatások, a hypotoniától való félelem megakadályozza a kívánt dózis elérését. A COPERNICUS tanulmányból [17] - amelybe 2289 beteget vontak be - egyértelműen kitűnt a carvedilol azon pozitív hatása, hogy a legalacsonyabb kezelés előtti szisztolés vérnyomású betegek vérnyomása carvedilolhatásban nemhogy csökkent, hanem emelkedett is. És mivel a legalacsonyabb szisztolés vérnyomású betegek bírtak a legnagyobb rizikóval, a carvedilolkezelés ebben a csoportban járt a legnagyobb abszolút kedvező hatással [18].

Több tanulmány igazolta, hogy a carvedilol a konvencionális terápia mellett alkalmazva csökkenti a mortalitást krónikus szívelégtelen betegekben kortól, nemtől, a szívelégtelenséget kiváltó októl, ejekciós frakciótól függetlenül. Emellett csökkent a hirtelen halál kockázata, valamint a hospitalizációk gyakorisága a carvedilolcsoportban placebóval összehasonlítva $[17,18]$.

\section{Carvedilol alkalmazása az intervencionális kardiológia mindennapi gyakorlatában}

$\mathrm{Az}$ intervenciós kardiológiai osztályon az ischaemiás szívbetegség minden formájával találkozunk a stabil angina pectoristól a cardiogen sokkot okozó myocardialis infarctusig, illetve a krónikus szívelégtelenségig. A betegek nagy százaléka magasvérnyomás-betegségben szenved és/vagy diabeteses. Koszorúér-intervenció esetén mindenképpen szükséges a megfelelő posztprocedurális gyógyszeres kezelés, amely egyrészt a behelyezett stent restenosisának, másrészt a de novo szúkületek megjelenésének rizikóját csökkentheti. Hibás szemlélet az, hogy a stent implantálásával a probléma megoldódott, hiszen valójában az okot nem szüntettük meg. Emiatt a gyógyszeres kezelés felépítésénél a fentieket is figyelembe kell venni. A carvedilol alkalmazása az intervenciót követően több szempontból is előnyös. Hemodinamikai hatásai ideálisak, kevésbé bradycardizál, mint a hagyományos béta-blokkolók, a perctérfogat nő, a szöveti vérátáramlást, a perifériás és renalis keringést javítja, jobban tolerálható.

Antioxidáns, simaizom-proliferációt gátló, migrációgátló hatása miatt (amely hatását a mitogénaktivált proteinkinázaktivitás és -reguláció befolyásolása révén éri el) joggal volt feltételezhető, hogy csökkenti a neointimaproliferációt, ezáltal a restenosis kialakulásának esélyét stentbehelyezést követően, de ezt igazoló nagy randomizált nemzetközi vizsgálat adata jelenleg még nem áll rendelkezésünkre. Várható pozitív hatásai miatt carvedilolkibocsátó stentet is alkalmaztak, bár eddigi adatok alapján két évvel a hálóbehelyezést követően csak trendszerû pozitív eredményeket értek el, szignifikáns restenosiscsökkenést nem [19].

\section{Következtetés}

A carvedilol számos olyan pozitív hatással rendelkezik, amely kiemeli a többi béta-blokkoló közül. Az intervenciós gyakorlatban kifejezetten érvényre jutnak ezek a pozitív hatások, mivel a szívkatéterezésre kerülő betegek nagy százalékban hypertoniások, diabetesesek vagy hyperlipidaemiások, a PAD-ban szenvedő betegek igen nagy százaléka koszorúér-betegségben is szenved. Kifejezetten előnyös az antioxidáns hatása, valamint simaizomproliferáció-gátló hatása, amely esetlegesen a stentrestenosis kialakulását is kedvezően befolyásolhatja, bár ezt alátámasztó randomizált vizsgálat még nem áll rendelkezésünkre. Összességében vasculoprotectiv hatása miatt ideális választás lehet stentbeültetést követően.

Anyagi támogatás: A közlemény megjelenését az Egis Gyógyszergyár Zrt. támogatta. 
A szerző a cikk végleges változatát elolvasta és jóváhagyta.

Érdekeltségek: A szerzőnek nincsenek érdekeltségei.

\section{Irodalom}

[1] Cutlip DE, Chhabra AG, Baim DS, et al. Beyond restenosis: fiveyear clinical outcomes from second-generation coronary stent trials. Circulation 2004; 110: 1226-1230.

[2] Dangas GD, Claessen BE, Caixeta A, et al. In-stent restenosis in the drug-eluting stent era. J Am Coll Cardiol. 2010; 56: 18971907.

[3] Morgan T, Snowden R, Butcher L. Effect of carvedilol and metoprolol on blood pressure, blood flow, and vascular resistance. J Cardiovasc Pharmacol. 1987; 10(Suppl 11): S124-S129.

[4] Opie L, Yusuf S. Beta-blocking agents. In: Opie LH, Gersh B. (eds.) Drugs for the heart, 6th ed. WB Saunders Company, Philadelphia, Pensylvania, 2005; pp. 1-32.

[5] Morgan T. Clinical pharmacokinetics and pharmacodynamics of carvedilol. Clin Pharmacokinet. 1994; 26: 335-346.

[6] Calò LA, Semplicini A, Davis PA. Antioxidant and antiinflammatory effect of carvedilol in mononuclear cells of hypertensive patients. Am J Med. 2005; 118: 201-202.

[7] Messerli FH, Grossman E. Beta-blockers in hypertension: is carvedilol different? Am J Cardiol. 2004; 93: 7B-12B.

[8] Sarafidis PA, Bakris GL. Antihypertensive treatment with betablockers and the spectrum of glycaemic control. QJM 2006; 99: 431-436.

[9] Kasiske BL, Ma JZ, Kalil RS, et al. Effects of antihypertensive therapy on serum lipids. Ann Intern Med. 1995; 122: 133-141.

[10] Brook RD. Mechanism of differential effects of antihypertensive agents on serum lipids. Curr Hypertens Rep. 2000; 2: 370-377.

[11] Maitland-van der Zee AH, Klungel OH, Kloosterman JM, et al. The association between antihypertensive drug therapies and plasma lipid levels in the general population. J Hum Hypertens. 2001; 15: 701-705.
[12] Giugliano D, Acampora R, Marfella R, et al. Metabolic and cardiovascular effects of carvedilol and atenolol in non-insulin-dependent diabetes mellitus and hypertension. A randomized, controlled trial. Ann Intern Med. 1997; 126: 955-959.

[13] Bakris GL, Fonseca V, Katholi RE, et al. Metabolic effects of carvedilol vs metoprolol in patients with type 2 diabetes mellitus and hypertension: a randomized controlled trial. JAMA 2004; 292: $2227-2236$

[14] The CAPRICORN Investigators. Effect of carvedilol on outcome after myocardial infarction in patients with left-ventricular dysfunction: the CAPRICORN randomised trial. Lancet 2001; 357: 1385-1390.

[15] Doughty RN, Whalley GA, Walsh HA, on behalf of the CAPRICORN Echo Substudy Investigators. Effects of carvedilol on left ventricular remodeling after acute myocardial infarction: the CAPRICORN Echo Substudy. Circulation 2004; 109: 201-206.

[16] Krum H, Hill J, Fruhwald F, et al. Tolerability of beta-blockers in elderly patients with chronic heart failure: the COLA II study. Eur J Heart Fail. 2006; 8: 302-307.

[17] Packer M, Fowler MB, Roecker EB, et al. Effect of carvedilol on the morbidity of patients with severe chronic heart failure: results of the carvedilol prospective randomized cumulative survival (COPERNICUS) study. Circulation 2002; 106: 2194-2199.

[18] Packer M, Coats AJ, Fowler MB, et al., for the Carvedilol Prospective Randomized Cumulative Survival Study Group. Effect of carvedilol on survival in severe chronic heart failure. N Engl J Med. 2001; 344: 1651-1658.

[19] Kim W, Jeong MH, Cha KS, et al. Effect of anti-oxidant (carvedilol and probucol) loaded stents in a porcine coronary restenosis model. Circ J. 2005; 69: 101-106.

(Kónyi Attila dr., Pécs, Ifjúság u. 13., 7623 e-mail: konyi.attila@pte.hu)

A közlemény megjelenését az Egis Gyógyszergyár Zrt. támogatta.

Az összefoglalóban szereplő információk a szerző nézeteit tükrözik.

Bármely említett termék alkalmazásakor az érvényes alkalmazási előírás az irányadó.

\section{A rendezvények és kongresszusok híranyagának leadása}

a lap megjelenése előtt legalább 40 nappal lehetséges, a 6 hetes nyomdai átfutás miatt. Kérjük megrendelőink szíves megértését.

A híranyagokat a következő címre kérjük: Orvosi Hetilap titkársága: edit.budai@akademiai.hu Akadémiai Kiadó Zrt. 